\title{
Introduction : Waging Health: Women in Nineteenth-Century American Wars
}

\section{Carmen Birkle and Justine Tally}

\section{(2) OpenEdition \\ Journals}

Electronic version

URL: https://journals.openedition.org/ejas/10665

DOI: 10.4000/ejas. 10665

ISSN: 1991-9336

Publisher

European Association for American Studies

\section{Electronic reference}

Carmen Birkle and Justine Tally, "Introduction: Waging Health: Women in Nineteenth-Century American Wars", European journal of American studies [Online], 10-1 | 2015, document 2.1, Online since 31 March 2015, connection on 08 July 2021. URL: http://journals.openedition.org/ejas/10665 ; DOI: https://doi.org/10.4000/ejas.10665

This text was automatically generated on 8 July 2021.

Creative Commons License 


\title{
Introduction : Waging Health: Women in Nineteenth-Century American Wars
}

\author{
Carmen Birkle and Justine Tally
}

\begin{abstract}
1 Thinking of war from a U.S.-American perspective will almost immediately evoke associations of male soldiers fighting heroic battles for a good cause such as democracy and/or the liberation of people from dictatorships, tyrannies, and torture. However, as more detailed and on-site news coverage has increasingly shown, this vision is entirely too limited. Among many possible revisionist perspectives is that of those women who have been involved in wars from a medical point of view and have significantly changed the life of soldiers through their work as doctors, nurses and care-givers. Among the more well-known, the British nurse Florence Nightingale revolutionized nursing and hygiene in the nineteenth century so that for the first time during the Crimean War there would not be more soldiers who died of diseases and infections rather than on the battlefield; and the Jamaican "doctress" and nurse, Mary Seacole, ran a hotel and became a mother figure for many soldiers during the same war. Louisa May Alcott not only worked as a nurse in a military hospital during the American Civil War but also translated her experiences into short stories that negotiate gender and ethnic issues (e.g., those of slavery and racism). Her texts pose both physical and moral conflicts, questioning the justification for the Civil War yet at the same time denouncing the injustices underlying the system of slavery. In a similar vein, the emerging group of American women doctors, among them most prominently Elizabeth Blackwell and Mary Walker, contributed their share of medical expertise at the time. As Jane E. Schultz shows in her comprehensive essay, "American women
\end{abstract}


were enthusiastic in their support of medical efforts during the Civil War" (363).

2 The nineteenth century is a decisive time in the development of medicine and the medical profession in Europe and North America. Not only did diseases such as cholera, typhoid, tuberculosis, yellow fever, and smallpox severely hit and decimate the population of both continents but medical experiments and doctors also began to find effective treatments for these devastating illnesses. While Benjamin Rush still had to rely on the traditional and in effect rather debilitating measures of bloodletting during the 1793 yellow fever epidemic in Philadelphia, the late nineteenth century testifies to the discovery of the Aedes aegypti mosquito as the harbinger of the yellow fever virus and to subsequent measures of fighting infection. While doctors in the disease-ridden Philadelphia still debated about the disease's origins, be they miasmic or imported, medical practitioners in the second half of the nineteenth century were already aware of the salubrious effects of air ventilation and, generally, well-implemented hygienic measures in, if possible, well-organized hospitals.

3 However, in spite of substantial insights into medical questions, a number of factors prevented some people from receiving adequate care, some people from practicing medicine, and some people from living long enough to be treated. U.S. America in the nineteenth century was prominently shaped by increased immigration and migration processes that brought more and more people into the country, some of whom immediately moved westward, thus further away from the Eastern cities that were, at least to some extent, able to provide some basic healthcare. On their westward journeys, people had to rely on folk knowledge of the respective cultures, on the occasional trained or untrained doctor who traveled with them, or on their own experiences with specific illnesses. The cities, though equipped with a number of medical practitioners including healers, quacks, as well as doctors, were at the same time the breeding ground of infectious diseases because of hierarchical class structures, poverty, unemployment, and no hygiene in tenement houses, with bed sharing as, for example, in New York City, as Jacob Riis demonstrates in his documentation How the Other Half Lives (1890).

4 In addition to class, ethnicity played a crucial role in the distribution of medical treatment. Not only did slaves receive scarcely hardly any medical treatment in the antebellum South, but they also suffered as free people of color in both the South or the North from a lack of financial means to secure adequate medical help. As is well known, slavery had its own rules and considered slaves chattel and property that needed to be taken care of only as long as they fulfilled their functions for their owners. However, even after the Civil War, with the granting of full civil rights to African American men, including the right 
to vote (in Amendments 13,14, and 15 to the Constitution), healthcare was not readily available.

5 The medical profession itself was far from being a homogenous entity. Homeopathy, Mesmerism and hypnoticism, hydropathy, and other schools emerged and competed with the traditional medical schools, socalled allopaths, for a well-paying clientele. Education and admission to practice were not regulated so that everyone who had worked as an apprentice to a medical practitioner was allowed to practice medicine, which gave, of course, rise to quackery, quacks traveling with medicine shows around the country to sell their (often ineffective) products. It was only with the foundation of the American Medical Association in 1847 that the medical profession received some structure and regulations. Subsequently, the study of medicine was more strictly organized.

6 One group for whom these substantial changes in the medical profession at first played only a marginal role were women. Their access to medical education was barred on account of gender with often the most ridiculous arguments of women as the weaker sex, being unable to manage the work of a physician or even a surgeon. The Victorian image of true womanhood, as explained by Barbara Welter, would furthermore put biological, social, and religious obstacles in their way. Their brains would be damaged if they pursued higher education; simultaneously, their reproductive organs would suffer and would no longer produce able and healthy leaders for the nation. Husband and children, if they had any, would be neglected if women studied medicine or even practiced it. They would forego their natural talents given to them by God, namely marriage and motherhood, and would contribute to the decline of the nation or even to "race suicide," to use President Theodore Roosevelt's words. Moreover, it was considered to be immoral for women to attend dissections, let alone to see a naked male body even if dead.

7 However, some women recognized their own calling, seized opportunities, and overcame all obstacles in becoming practitioners with or without college degrees. Elizabeth Blackwell was the first American woman who studied medicine, at Geneva Medical College in New York State, and received her degree after two years, officially graduating in 1849 at the top of her class. She went to Europe (England and France) to complete her education since U.S. hospitals and patients were reluctant to accept women doctors. Although European medical institutions were, in most cases, as reticent about admitting women, they often did offer special classes for medical students and doctors from abroad for admission fees and were not interested in gender but the economic profit these classes would yield. Many generations of North American doctors - male and female - flocked to hospitals and universities in London, Paris, Zurich, Berlin, and Vienna to enhance 
their knowledge of the most recent developments in medical research and treatment.

8 When Blackwell returned, she began to practice as an independent doctor at first, contributed her share of work to war hospitals during the Civil War, and eventually founded the New York Infirmary as both a hospital for women and children and an adjacent college for women, hired the few experienced and licensed women doctors as teachers, and sent her own graduates to hospitals and schools in Boston and Philadelphia. The number of women's medical colleges steadily increased until, gradually, a number of medical schools began to become co-educational and the need for separate education decreased even though many male professors still refused, or at least had problems with, teaching medicine to young women.

9 As can easily be seen, the medical profession underwent substantial changes in the nineteenth century. The Civil War (1861-65) did not necessarily help progress in the profession, but it did create the need for a large number of medical personnel who - trained or untrained would volunteer to work in war hospitals. In spite of all the prejudices and stereotypes about women nurses and doctors, the patients, and the Army as such, could simply not afford to afford to reject female volunteers. Florence Nightingale was convinced that every woman was a nurse because in families it was women's task to nurse children, husbands, and other family members back to health.

10 Wars bring about the best and worst in people; wars are life out of order, and soldiers need care if wounded or otherwise ill. Women practiced as nurses and, occasionally, as doctors, in the Civil War as well as, at the end of the nineteenth century, in the Spanish American War (1898-99). For the soldiers, they were often mother substitutes, angels in the battlefield, or reminded them of their beloved back at home. Documents that render these women's experiences are often not only diaries and letters, travelogues, longer autobiographical accounts, but also court and Army records as well as fictionalized narratives.

11 The essays that follow in this half issue on women and health in war focus on the nineteenth-century American Civil War and the Spanish American War. Not only do they unveil the large number of women who were involved in the healing of the nation's soldiers - whether of the Union Army or the Confederacy - but also include pertinent observations on the nation's poor as well as black people, such as the free people of color, who did not receive adequate treatment through official channels. The testimonials discussed in these essays expose the horrendous sufferings of soldiers, on the one hand, and the trials of the women - both black and white - who tried to help, on the other hand.

${ }_{12}$ Closely examining the diary and letters of abolitionist Laura M. Towne, Antje Dallmann unveils the socio-historical context of the work 
of a homeopathic nurse on St. Helena Island during and after the Civil War. In addition, her use of discourse analysis throws light on the precarious conditions of the newly freed people as well as on the restrictions on a woman intent on providing them with healthcare. For Dallmann, the omission of any discussion of the medical crisis in the postwar era is also indicative of a "crisis of representation of contemporary white women's roles, obligations, aspirations, and their assumed entitlement." Moreover, the essay is also a thoughtful commentary on colonialist concepts of African Americans (as "insects" who "swarm" about the island, for example). Using the "trope of teaching health in an unhealthy environment" reveals Towne's writing to be a "major site of a class-specific, gendered, and racialized struggle over prestige and authority within the public realm."

13 In "Dangerous Liaisons," E. Susan Barber and Charles F. Ritter offer an in-depth review of the historical documents that testify to the social justice (or lack thereof) afforded to working women who provided services (washing, cooking, cleaning, mending) to the armies fighting the Civil War, including soldiers who assumed that sexual services were included. Though all too often unprotected by the law, more than just a few women, both black and white, took their grievances before the military and civilian courts with varying success. The case studies offered by Barber and Ritter open a fascinating window on the plight of women who managed to survive financially through the war by attaching themselves to the troops, yet whose existence was at best precarious. Perhaps most startling is the number of times the women were actually afforded redress and the perpetrators punished.

${ }_{14}$ Daniela Daniele specifically examines Louisa May Alcott's recourse to humor and satire in order to portray the grim realities of nursing during the Civil War. Drawing on her own personal war experience, Alcott employs a semi-autobiographical narrator in her Hospital Sketches to contrast the expectations of providing a "domestic environment" and a family atmosphere of "laughter and compassion" for the wounded soldiers with the all too often sordid conditions of a war hospital. The protocol for caring for these men was domestic in nature, lending a metaphorical implication to the nurses' work. The moral work of the so-called "Deaconesses" becomes part and parcel to the reparations of a nation torn asunder by fratricidal war in an effort to "restore order in the national family." Daniele specifically signals Alcott's use of irony to play down the miseries of the situation while simultaneously portraying the "rampant masculinization" of the female nurses as a counterbalance to the "emasculating injuries" of the defeated soldiers.

15 Despite the myth of "ideal womanhood" of the nineteenth century ("pure, pious, domestic and submissive"), Kirsten Twelbeck argues that the roles taken up by women as nurses on both sides of the Civil War and during the decades thereafter offered the possibility of 
wielding power and authority (both limited) as nurses in the conflict and as health workers among severely disadvantaged populations. Yet the ascension of women to positions of medical respect also required a change in the discourse of the contemporary society, often through the literary production of the Era of Reconstruction. Authors who had actually served as nurses as well as those who used the examples of service women in their narratives bandied about concepts of "malehood" and the threat of emasculation by strong ("unruly") caregiving women. What Twelbeck describes as "an increasing alienation between the genders" during the decades after the Civil War is illustrated in her placing Louisa May Alcott's Hospital Sketches (originally published in 1863) and Charlotte Perkins Gilman's all-female utopia Herland (1915) as well as the lesser known Mizora by Mary Bradley Land (serialized between 1880 and 1881) in dialogue with Silas Weir Mitchell's "The Case of George Dedlow" (which examines "postwar male anxieties") and Alonzo F. Hill's John Smith's Funny Adventures on a Crutch (in a "metaphorical re-mapping of the nation" through the eyes of a one-legged veteran [1869]). Like Huck Finn, Smith finds himself much happier in the "Territory" rather than in the "feminized" society of the East Coast.

${ }_{16}$ While in the Civil War, Northern and Southern soldiers fought against each other on familiar U.S. territory, the Spanish American War took them away from their country to Cuba, Puerto, or the Philippines and, thus to wholly unfamiliar climates. Not only did soldiers more frequently die of tropic illnesses, such as malaria, as well as of diseases known from home, such as dysentery, typhoid, or yellow fever, but also from inadequate hygiene and nourishment. Similarly, doctors and nurses - male or female - had to fight these diseases and frequently also succumbed to them. The only difference with respect to the context of the Civil War was that many more nurses had actually received training and were army contract nurses of the permanent Army Reserve Nurse Corps.

17 Even though women had been released from any military service after their contribution to the American Civil War, Ingrid Gessner reveals just how instrumental nurses were in the Spanish American War at the turn of the nineteenth into the twentieth century. No longer directly involved in the military, women nevertheless had access to newly-established training programs which eventually became affiliated with every major hospital. Through the determined dedication of (and strong-arming by) major female figures, who refused to be thwarted by a male-dominated medical establishment, nurses were finally recognized in the establishment of the Army Reserve Nurse Corps in 1901. Gessner celebrates the lives and work of two women in particular, Anita Newcomb McGee and Clara Louise Maass, who through their exemplary service and sacrifice were instrumental in achieving the recognition nurses deserved. That recognition was slow and hard won, yet Gessner's contribution to this little-known aspect of women's history 
makes clear just how crucial their work was both during their lives and as pillars for future achievements.

18 "Women and Health in Nineteenth-Century American Wars" remains an under-researched area in both military and medical history as well as in literary and cultural history in the United States. Further investigations into the many personal and public records reveal a history of women who went to war to heal but had to fight their own gender war against gender-specific prejudices, derision, and a normative belief system as well as against physical violence. Yet, their work was tireless and magnanimous; healing the soldiers and, by extension, the nation was their crucial contribution to the war efforts.

\section{BIBLIOGRAPHY}

Riis, Jacob A. How the Other Half Lives: Studies among the Tenements of New York. 1890. Pref. Charles A. Madison. New York: Dover, 1971.

Schultz, Jane E. “The Inhospitable Hospital: Gender and Professionalism in Civil War Medicine." Journal of Women in Culture and Society 17.2 (1992): 363-92.

Welter, Barbara. “The Cult of True Womanhood: 1820-1860." American Quarterly 18.2 (1966): 151-74. 